\title{
FRANTZ'S TUMOR OF THE PANCREAS
}

\author{
Tumor de Frantz do pâncreas \\ Expedito Aguiar BACELAR-JÚNIOR, Marcos André Pereira GOMES, Orlando Jorge Martins TORRES, \\ Letácio José SANTOS, Karenn Barros BEZERRA, Andréa Rodrigues de SOUZA
}

Trabalho realizado no Departamento de Radiologia do Hospital Centro Médico Maranhense/Instituto de Radiologia São Luís e no Serviço de Cirurgia do Hospital UDI, São Luís,MA, Brasil.

HEADINGS - Pancreatic neoplasms. Carcinoma, papillary. Pancreatectomy.

\section{Correspondence:}

Karenn Barros Bezerra,

e-mail: karennbezerra@hotmail.com

Fonte de financiamento: não há

Conflito de interesses: não há

Recebido para publicação: 18/08/2009

Aceito para publicação: 14/06/2010

HEADINGS - Neoplasias pancreáticas. Carcinoma papilar. Pancreatectomia
ABSTRACT - Background - The solid-cystic tumor of the pancreas is rare, and had several names, including "papillary cystic tumor," "solid cystic tumor," "solid and papillary epithelial neoplasm." About $90 \%$ of cases are found in young women, measuring between seven and $20 \mathrm{~cm}$ in diameter, with $40 \%$ of them in the head, tail $32 \%$ and $28 \%$ in the body. Case report - Woman of 29 years was admitted for investigation of strong and persistent pain in right hypochondrium. It was performed ultrasonography and abdominal computed tomography, showing lobulated mass with the consistency of soft parts in the tail of the pancreas, peripheral capsular enhancement and hypovascular center measuring $5.5 \times 5,5 \times 5,0$ $\mathrm{cm}$. MRI better defined, with intermediate signal on T1 and T2, small scattered foci of low signal on T2 and peripheral enhancement by gadolinium, suggesting tumor Frantz. She underwent parcial pancreatectomy and total splenectomy. Macroscopic and microscopic findings suggested, and immunohistochemistry confirmed the diagnosis. Conclusion - Should be considered this tumor in the differential diagnosis of abdominal masses in young women.

RESUMO - Introdução - O tumor sólido-cístico do pâncreas é raro, e teve várias denominações, entre elas "tumor cístico papilar", "tumor cístico sólido", "neoplasia epitelial sólida e papilar". Cerca de $90 \%$ dos casos são encontrados em mulheres jovens, medindo entre sete a 20 centímetros de diâmetro, estando $40 \%$ deles na cabeça, 32\% na cauda e $28 \%$ no corpo. Relato do caso - Mulher de 29 anos foi admitida para investigação de fortes e persistentes dores em hipocôndrio direito. Foram realizados ultrassonografia e tomografia computadorizada de abdome, mostrando massa lobulada, com consistência de partes moles na cauda do pâncreas, realce capsular periférico e centro hipovascular medindo 5,5x5,5x5,0 cm. A ressonância magnética definiu melhor, com sinal intermediário em T1 e T2, pequenos focos esparsos de hipossinal em T2 e realce periférico pelo gadolíneo, sugerindo tumor de Frantz. Foi submetida à pancreatectomia caudal e esplenectomia total. Achados anatomopatógicos macroscópicos e microscópicos sugeriram, e o estudo imunoistoquímico confirmou o diagnóstico Conclusão - Deve-se considerar esta neoplasia no diagnóstico diferencial de massas abdominais em mulheres jovens.

\section{INTRODUCTION}

$\mathrm{F}$ irst described in 1959 by Frantz, this solid-cystic tumor of the pancreas is rare ${ }^{5}$, and had several names, including "papillary cystic tumor," "solid cystic tumor", "solid epithelial neoplasm and papillary. Established in the literature as Frantz tumor, increased it's incidence from $0.17 \%-2.7 \%$ to $6 \%$ from 1980 to 20058 . However less than 900 cases were described in the literature. The authors report a case in a young female and make a brief discussion in terms of diagnosis, treatment and prognosis.

\section{CASE REPORT}

Female, 29 years old, married, housewife, since 2004 reported some sporadic pain in the right hypochondrium, moderate intensity, without irradiation, relief with ingestion of analgesics, without jaundice, fever or anorexia. Clinical investigation was inconclusive at this time. Four years later 
she was affected by a sudden sharp epigastric pain in bar, radiating to the back, followed by vomiting, treated in the emergency room. Remained asymptomatic for two months when she began to have right hypochondrium pain. Ultrasound and computed tomography, showed lobulated mass with soft tissue attenuation on the tail of the pancreas, with peripheral contrast enhancement and central area of hypovascular density, measuring $5.5 \times 5,5 \times 5,0 \mathrm{~cm}$. Magnetic resonance imaging was better to define the lesion at the site, with intermediate signal intensity on $\mathrm{T} 1$ and $\mathrm{T} 2$, scattered small foci of low signal on T2 and peripheral enhancement by gadolinium, suggesting Frantz's tumor. She was submitted to caudal pancreatectomy and splenectomy. Histopathology findings suggested, and immunohistochemical study confirmed the diagnosis. Currently, she is asymptomatic in the fourth cycle, in a series of six cycles of chemotherapy with good response.

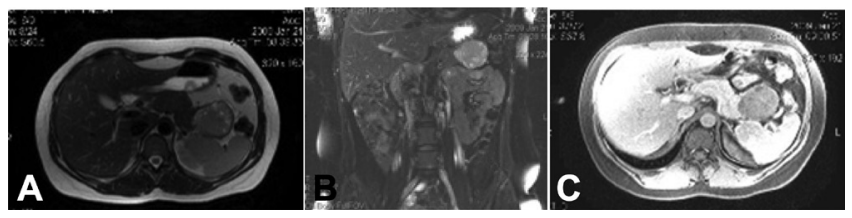

FIGURE 1 - A and B: axial T2WI MR and coronal STIR MR showing solid mass with small cysts in pancreatic tail (C); axial T1 C+ MR shows peripheral enhancing

\section{DISCUSSION}

Frantz's tumor is a rare cancer of the pancreas of unknown etiology, but appears to originate from pancreatic pluripotentes ${ }^{5}$ cells. Embryogenic cells may remain in the pancreas during embryogenesis, differentiating the tumor. Recently, there has been significant increase in incidence, probably due to a greater knowledge of the disease and a greater uniformity of conceptualization ${ }^{2}$. About $90 \%$ of cases are found in young women (second and third decades), measuring between seven to eight inches in diameter, throughout the pancreas, with $40 \%$ of them in the head, tail in $32 \%$ and $28 \%$ in body ${ }^{6}$. The preference for females suggests that hormonal factors may be involved in the pathogenesis of tumor ${ }^{1,3}$, but there is controversy about the presence or absence of estrogen receptors and progesterone receptors in these tumors ${ }^{7,8}$. Clinically, it manifests itself as an asymptomatic slow growth ${ }^{6}$ abdominal mass or with nonspecific symptoms. In this case, the patient had abdominal pain in bars, associated with vomiting, which allowed the diagnosis after performing imaging and histopathology. CT and MRI of the abdomen revealed a pancreatic mass encapsulated cystic-solid consistency. This tumor has a benign evolutionary behavior and good prognosis, even when presented with metastases at diagnosis, most often located in the liver ${ }^{7}$. This patient had tumor confined to the pancreas. The differential diagnosis includes: isolated nonfunctional tumor, acinar cell carcinoma, papillary cyst adenoma, serous cyst adenoma, pancreatic carcinoma and child pseudocyst ${ }^{6}$. Complete surgical resection or pancreatectomy is often sufficient as a therapeutic option, but if necessary, can be complemented with chemotherapy, with good results. In this case, it was decided to partial pancreatectomy and splenectomy, followed by chemotherapy sessions. The patient responded satisfactorily to medical and surgical treatment and is currently asymptomatic on follow-up.

\section{CONCLUSION}

Frantz tumor should be considered in the differential diagnosis of abdominal masses in young women.

\section{REFERENCES}

1. Bostanoglu S, Otan E, Akturan S, Hamamci EO, Bostanoglu A, Gokce A, Albayrak L. Frantz's Tumor (Solid Pseudopapillary Tumor) of the Pancreas. J Pancreas (Online) 2009; 10(2):209-211.

2. Costa-Neto GD, Amico EC, Costa GID. Tumor sólido-cístico pseudopapilar do pâncreas (Tumor de Frantz): Estudo de quatro casos. Arq Gastroenterol 2004; 41(4): 259-262.

3. Cuéllar OZ, Hernández TR, Benavides RB, Aceves RR. FrantzGruber tumor: a case report. Rev Gastroenterol Mex 2004; 69(4): 235-238.

4. Freda F, Procaccini E, Ruggiero R, Antropoli M, Manganiello A, Nunziata L, Petronella P, Lo Schiavo F. Solid-cystic pseudopapillary tumor of pancreas: description of two cases and literature review. Tumori. 2007; 93(5): 522-5.

5. Kosmahl M, Seada LS, Jänig U, Harms D, Klöppel G. Solidpseudopapillary tumor of the pancreas: its origin revisited. Virchows Arch. 2000; 436(5): 473-80.

6. Macedo TA, Vieira SC, Oliveira AM, Coelho EG, Santos LG, Santana JOI. Tumor de Frantz: Relato de um Caso. Revista Brasileira de Cancerologia 2004; 50(1): 33-35.

7. Pinto FEL, Moraes MV, Oliveira AGF. Papyllary cystic tumor of the pâncreas. Rev Col Bras Cir, 2001; 28(3): 304-306.

8. Siquini W, Marmorale C, Guercioni G, Stortoni P, Bearzi I, Fianchini A, Landia E. Solid pseudopapillary tumor of the pancreas. A report of 3 cases and a review of the literature. Chir Ital 2006; 58(2): 235-45. 